\title{
Pyritized microfossils in palynological slides from the Late Cretaceous of Colombia
}

\author{
KLAUS F. PRÖSSL ${ }^{1, *} \&$ JOACHIM R. GRÖSSER ${ }^{2}$ \\ ${ }^{1}$ Fraport AG, IUK-PM, 60547 Frankfurt, Germany \\ ${ }^{2}$ Institut für Umweltanalytik und Geotechnik GmbH, Christian-Kremp-Str. 14, 35578 Wetzlar, Germany \\ ${ }^{*}$ Corresponding author (e-mail: klausproessl@gmx.net)
}

\begin{abstract}
Palynological investigations of Late Cretaceous to Tertiary sediments of the Andes in Colombia yielded some distinct groups of palynoclasts recovered as pyritized remains of diatoms, radiolaria and foraminifera. The different processes of pyritization are illustrated and the palaeontological use of these fossils is discussed. Techniques for investigating such opaque microfossils are also suggested. J. Micropalaeontol. 28(1): 45-52, May 2009.
\end{abstract}

KEYWORDS: pyritization, diatoms, radiolaria, foraminifera, Cretaceous

\section{INTRODUCTION}

Many groups of microfossils are obtained by digesting sediments using the standard palynological preparation technique (e.g. Traverse, 1988). The approach exploits the composition of organic and inorganic material resistant to non-oxidizing acids. Normally, this palynodebris is composed of organic residues, such as sporopollenin (pollen, spores, dinoflagellate cysts, acritarchs), chitin (chitinozoa, scolecodonts, foraminiferal inner test linings, fungal spores), lignin/cellulose (woody remains), cutin (cuticles) and similar material. In special circumstances, these fossils are preserved as opaque forms which are coalified, carbonized or rarely pyritized. Besides the use of scanning electron microscopy, only a combination of reflecting light and transmitted light (CRT) allows these palynomorphs to be investigated.

During research for the priority programme 'Global and Regional Controls on Biogenic Sedimentation: Reef-Evolution and Cretaceous-Sedimentation' of the Deutsche Forschungsgemeinschaft, sediments of Cretaceous age were sampled from Colombia (South America). As the aim was to derive data for interpretation of climatological changes, a widespread sampling from the Cundinamarca Basin and adjacent areas was carried out (Fig. 1). Unfortunately, only rarely did samples yield palynomorphs; most of the gathered rocks proved to be barren due to thermal alteration. However, in some cases these sediments contained pyritized remains of microfossils, such as foraminifera, radiolaria and diatoms, which provide material for this paper.

\section{LOCALITIES}

The studied rocks are grey to dark grey, comprising more or less calcareous marls. The localities and the dominant microfossil groups present are as follows:

1. Section along the road from Las Mesitas de El Colegio to Bogotá at milestone $27 \mathrm{~km} 832 \mathrm{~m}$ (for details, see CáceresGirón \& Etayo-Serna (1969) and Etayo-Serna (1979)), Cundinamarca Basin (Fig. 1), La Frontera Formation. The age, based on ammonites, is Turonian.

(a) Sample No. 26-10-01-90 yielded mainly radiolaria with very rare, broken diatom frustules and;

(b) Sample No. 26-10-14-90, which yielded mainly foraminifera with rare radiolaria.
2. Section along the road from Santa Fe de Antioquia to Dabeiba, NW of Giraldo near Cañas Gordas, Cauca Valley, Western Cordillera (Fig. 2), Penderisco Formation, which is suggested to be Late Cretaceous by lithological comparison. Internal moulds of diatoms in sample 25-6-6.

All the lithologies investigated have been thermally altered up to $180-200^{\circ} \mathrm{C}$ as indicated by an almost total lack of palynoclasts, with remaining palynomorphs being highly carbonized and nearly completely destroyed (Gaupp \& Batten, 1985; Prössl, 1992). Marshall \& Batten (1988) also reported pyritized radiolarian skeletons from the Saxonian Basin (NW Germany) in a palynomorph-bearing profile, but without such extreme thermal alteration - the palynomorphs were transparent.

Poorly preserved palynoclasts (see Prössl, 1997) occur in samples from a profile in the central part of the Cretaceous Cundinamarca Basin. Additionally, pieces of crystalline pyrite and graphite were found, which contain opaque palynoclasts, including pyritized fragments of diatoms, radiolaria and foraminifera. Both samples from the La Frontera Formation show a thermal influence as the palynodebris has been carbonized or destroyed. This is a product not only of the overburden of the younger sediments, but Late or post-Cretaceous intrusions may also have been responsible for the thermal metamorphism (McLaughlin \& Arce, 1971).

Similar alteration must be postulated for the sample with the internal moulds of diatoms from the Western Cordillera (locality 2). Apart from these remains only framboids, crystalline pyrite and graphite were present. The thermal alteration of this area may additionally be a product of Andean folding.

\section{METHODS}

Investigation of opaque microfossils using a combination of reflecting light and transmitted light (CRT) is an alternative method, avoiding the expensive preparations usual for scanning electron microscopy (Prössl, 1996). These methods make the shape and the surface visible and, in special cases, allow the determination of the genus, and occasionally species. Furthermore, the use of differential interference contrast (DIC) in reflecting light produces an essential improvement in the image resolution.

The samples in this study were prepared using common palynological methods, namely hydrochloric acid $(\mathrm{HCl})$, 


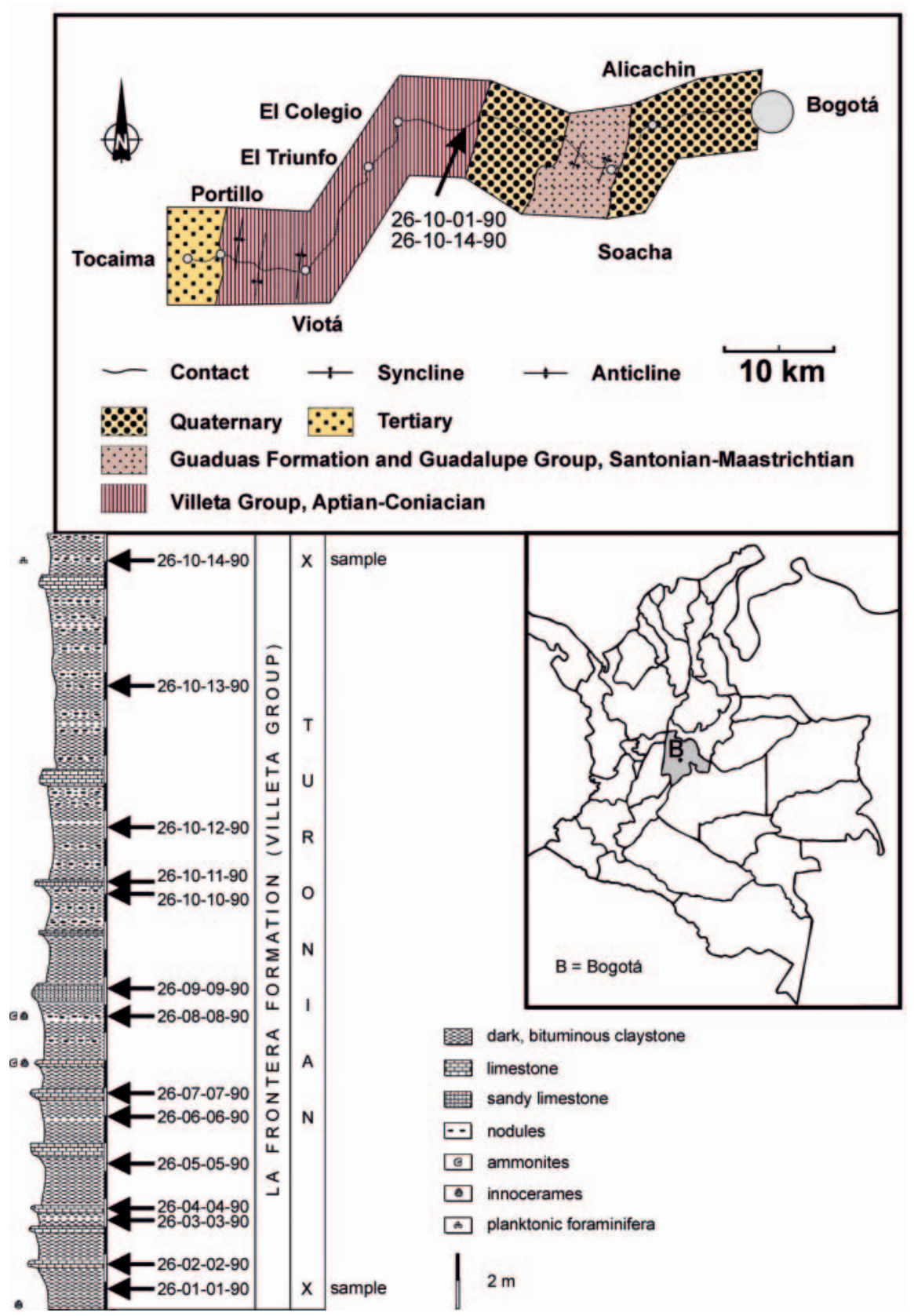

Fig. 1. Map showing the locations of sample No. 26-10-01-90 and 26-10-14-90 along the Las Mesitas de El Colegio road to Bogotá at 27 km 832 m, Cundinamarca Basin. Map after Cáceres-Girón \& Etayo-Serna (1969), profile by Grösser \& Senff (1990, unpublished).

hydrofluoric acid (HF) and sieving. The residues were mounted in glycerin jelly.

The material is stored in the collection of the palaeobotanical section at the Forschungsinstitut und Naturmuseum Senckenberg, Kuhwaldstraße 55, D-60486 Frankfurt/Main (Numbers SM.B. 17585 to SM.B. 17 588).

\section{PRESERVATION OF PYRITIZED MICROFOSSILS}

The discovery of calcareous or siliceous microfossils, which are normally destroyed during palynological preparation by $\mathrm{HCl}$ and $\mathrm{HF}$, is unusual. If palynomorphs occur in sediments their organic material is translucent, coalified or carbonized after fossilization. The microfossils discussed here have been preserved in pyrite, where either the original skeleton- or shellmaterial (e.g. opal, calcite and aragonite) or internal moulds have been substituted by pyrite (Krumbiegel \& Krumbiegel, 1981). The iron from the sediment or pore water reacted with the sulphur of the hydrogen sulphide, which originated from decomposing organic material (Canfield \& Raiswell, 1991; see also Bartels et al. 1998):

$$
\begin{aligned}
& 18 \mathrm{CH}_{2} \mathrm{O}+9 \mathrm{SO}_{4}{ }^{2-} \rightarrow 18 \mathrm{HCO}_{3}{ }^{-}+9 \mathrm{H}_{2} \mathrm{~S} \\
& 6 \mathrm{FeOOH}+9 \mathrm{H}_{2} \mathrm{~S} \rightarrow 6 \mathrm{FeS}+3 \mathrm{~S}^{0}+12 \mathrm{H}_{2} \mathrm{O}
\end{aligned}
$$



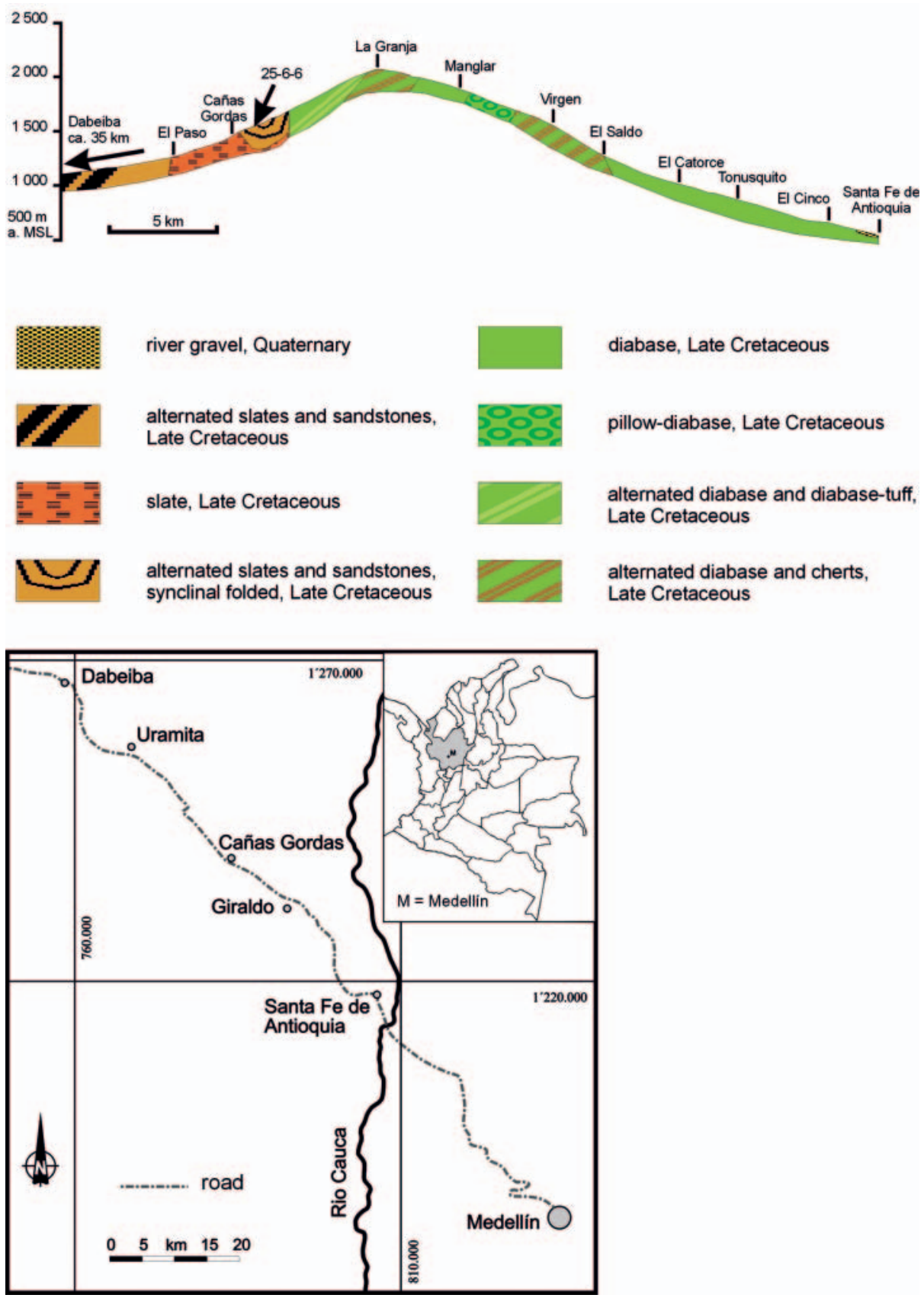

Fig. 2. Location of sample 25-6-6 along the road from Santa Fe de Antioquia to Dabeiba, NW of Giraldo, Cauca Valley, Western Cordillera. Profile after Stibane from Grösser (1989).

$$
\begin{gathered}
6 \mathrm{FeS}_{2}+3 \mathrm{~S}^{0} \rightarrow 3 \mathrm{FeS}_{2}+3 \mathrm{FeS} \\
\mathrm{H}_{2} \mathrm{~S}+\mathrm{FeS} \rightarrow \mathrm{FeS}_{2}+\mathrm{H}_{2}
\end{gathered}
$$

The pyrite resulting from this chemical reaction allows the preservation of these fossils in palynological preparations, whereas normally the skeleton- or shell-minerals are destroyed during palynological preparation.

Diatoms in this material occur in different phases and kinds of pyritization. Sometimes pyrite appears to form inside the frustules of diatoms. Initially, single pyrite framboids are evi- dent inside the frustule (Pl. 1, figs 14, 15; Pl. 2, fig. 5), with increasing size, the framboids join together (Pl. 1, figs 1, 2; Pl. 2, figs 1,2$)$ and finally they coalesce to preserve the inner structure of the frustules as internal moulds (Pl. 1, figs 7-9; figs 10-13; Pl. 2, figs 9-12). In single specimens a rare polygonal shape of the pyrite may occur (P1. 2, fig. 4). A very similar preservation was described by Geroch (1973) from Early Cretaceous black shales of the Polish Carpathians. Some very rare specimens show a pyritization of the siliceous frustule itself (pseudomorphism, Pl. 2, figs 6-8). This type of pyritization also preserves radiolaria. Both types of preservation of the diatoms (internal 


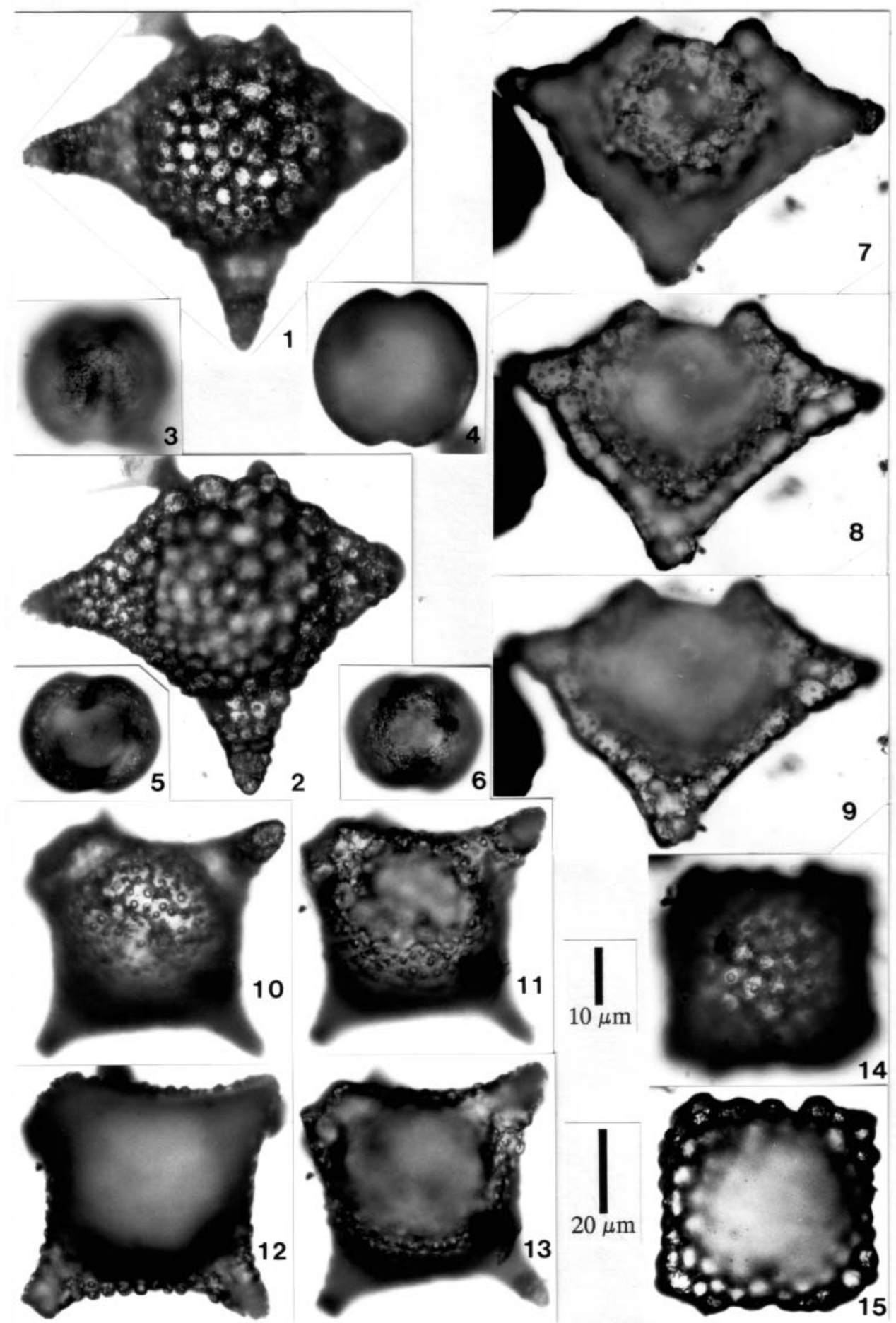

Explanation of Plate 1.

figs 1-15. Diatoms and problematica: 1, 2, cf. Trinacria sp. or cf. Amphitetras sp. (cf. ?Triceratium sp.). The framboids are clearly visible; because they have not completely grown together, a pseudoreticulum is built. Some pores can be recognized $(31.8-115.5) ; 3,4$, gen. et sp. indet., sphere with a notch and incomplete fine polygonal reticulum (34.5-120.4); 5, 6, gen. et sp. indet., sphere with a notch and complete fine polygonal reticulum (39.8-117); 7, 8, 9, cf. Trinacria sp. or cf. Amphitetras sp. (cf. ?Triceratium sp.). The framboids have nearly coalesced and the distribution of the pores is visible. A marginal rim is present (33.8-121.1); 10, 11, 12, 13, cf. Trinacria sp. or cf. Amphitetras sp. (cf. ?Triceratium sp.). The framboids are merged and the distribution of the pores is visible. Sometimes it looks as if the pyrite has grown into the pores of the frustula (38.2-113.4); 14, 15, cf. Trinacria sp. or cf. Amphitetras sp. (cf. ?Triceratium sp.). The framboids are clearly visible, a pseudoreticulum is present and the frustule was not completely filled. Some pores can be recognized (34-120). For figures $1-4$ and 7-15, magnification is $\times 750(20 \mu \mathrm{m}$ scale); for 5 and 6 it is $\times 1000$ (10 $\mu \mathrm{m}$ scale). All objects are from slide 25-6-6-III, reference point 53.1-117.2. Coordinates given for respective figures. All photomicrographs were taken with CRT/DIC. Suggested age is Late Cretaceous/Tertiary. 

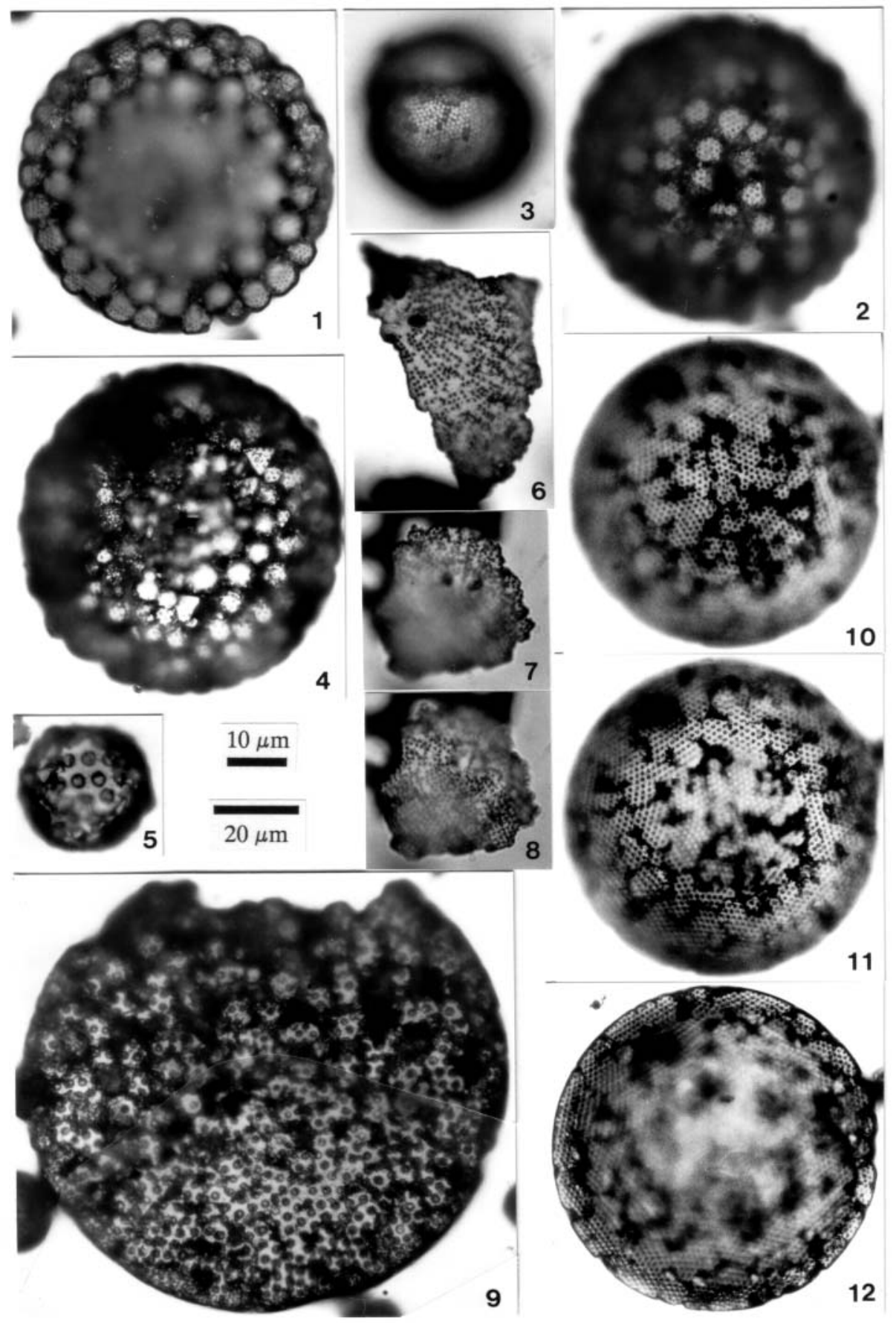

Explanation of Plate 2.

figs 1-12. Diatoms and problematica: 1, 2, cf. Stephanopyxis sp.; the framboids have not completely grown together and on their surfaces some pores can be recognized (38-121.8); 3, gen. et sp. indet., sphere with a notch well-preserved fine polygonal reticulum (28.2-115.1); 4, cf. Stephanopyxis sp.; besides the rounded framboids a rare polygonal form of pyrite occurs. The black areas are holes that were not filled with pyrite during framboid growth (33.4-110.2); 5, single framboid which belongs possibly to the group of cf. Coscinodiscus sp. (cf. Aulacodiscus sp.) (39.6-117); 6, cf. Archaemonadopsis sp., cf. Trochosiropsis sp., cf. Aulacodiscus sp., cf. Pyrgodiscus sp. or cf. Sheshukovia sp.; the pyritized frustule shows four rudiments of broken spines with very fine pores (43.2-124.3); 7, 8, cf. Archaemonadopsis sp., cf. Trochosiropsis sp., cf. Aulacodiscus sp., cf. Pyrgodiscus sp. or cf. Sheshukovia sp.; the frustule is pyritized and shows two rudiments of broken spines. The pores are very fine (39.8-122.5); 9, cf. Coscinodiscus sp. (cf. Aulacodiscus sp.); the upper part of the mould was destroyed and broken into pieces, as in figure 5. The pores are bigger than in the other specimens $(43.6-117.6) ; \mathbf{1 0}, \mathbf{1 1}, 12$, cf. ?Stellarima sp. (c. $\times 750)$; pyritic inner mould of a diatom with well-recognizable fine pore structures (43-112.5). For figures 1, 2, 4 and 9-12, magnification is $\times 750(20 \mu \mathrm{m}$ scale); for 3 and 5-8, it is $\times 1000(10 \mu \mathrm{m}$ scale). All objects are from slide 25-6-6-III, reference point 53.1-117.2. Diatoms of figures 3 and 6-8 are from slide 26-10-01-90, reference point 53.8-117.2, and those of figures 10-12 are from slide 25-6-6-I, reference point 55-117.3. Coordinates given for respective figures. All photomicrographs were taken with CRT/DIC. Suggested age for slides 25-6-6-I and 25-6-6-III is Late Cretaceous/Tertiary; for 26-10-01-90, it is Late Cretaceous (Cenomanian/Turonian). 
moulds and pyrite frustules) must have happened at an early stage of diagenesis, before the sediment was heated up to $50^{\circ} \mathrm{C}$, because frustules do not survive above this temperature (Barron, 1993). Only the presence of pyrite allowed preservation of the diatoms during the formation of the Andes, with thermal activity up to $200^{\circ} \mathrm{C}$ or more which has consequently destroyed the organic parts of the palynomorphs.

Among organisms with siliceous skeletons, radiolaria and their fragments are most frequently well preserved in pyrite as pseudomorphs. Not only do the gross structures of the skeleton survive (Pl. 3, fig. 13), but also the finest parts, such as the cephalis and thorax of nassellarian radiolaria (Pl. 3, figs 3, 4, 10, 11), and the inner medullary shells of spumellarian forms ( $\mathrm{Pl} .3$, figs 5-7); in contrast, spines are rarely preserved.

The $\mathrm{CaCO}_{3}$ tests of foraminifera likewise have been pyritized (Pl. 3, figs 1, 2, 8, 9, 12). Some broken individuals show internal chambers which may be filled by the growth of large pyrite crystals (P1. 3, fig. 12). Wall surfaces are roughly preserved with small crystals, but occasionally a slight ornamentation is visible (Pl. 3, figs 2, 8, 9).

Unusually, in sample 26-10-14-90 one can see the association of pyritized skeletons of different primary composition, with foraminifera and radiolaria occurring together. Perhaps pyritization did not occur immediately and transformation included an intermediate composition in either the $\mathrm{SiO}_{2}$-skeletons of the radiolaria or the $\mathrm{CaCO}_{3}$-tests of the foraminifera. Using scanning electron microscopy, both groups of fossils were shown to be composed of pyrite (Coutts, unpublished report, 1999). The cause apparently is the method of maceration $(\mathrm{HF}, \mathrm{HCl})$, which destroyed the skeleton minerals, and thermal alteration, which destroyed the organic layers. Reworking of the fossils is unlikely because of the good preservation of the finest details in both groups, but it must be considered a possibility.

\section{USE OF PYRITIZED FOSSILS}

Unfortunately, the preservation of pyritized fossils allows no detailed identification and so a precise stratigraphical determination is not possible. However, some general determinations were possible and are denoted below.

Diatoms from this material occur as internal moulds and lack detail in the outer surface of the frustule. Without exception, the specimens are members of the centrales $(\mathrm{Pls} 1,2)$ and therefore are planktonic genera. J. Fenner (pers. comm., 2000) analysed the shape and the distribution of the pores of the internal moulds. The quadrangular forms (Pl. 1, figs 1, 2, 7-15) are attributed to the genera Trinacria or Amphitetras, or possibly to Triceratium. The centrales (Pl. 2) were suggested to belong to the genera Stephanopyxis (P1. 2, figs 1, 2, 4), Stellarima (P1. 2, figs 10-12) and Coscinodiscus or Aulacodiscus (Pl. 2, fig. 9). Due to the long range of these genera, the age of the sediments is suggested to be Late Cretaceous to Tertiary. The forms present preferred colder areas or, as in this case, upwelling regions with high nutrient contents, and lived within the inner to outer parts of the shelf, or in shallow water.

Identification of the pyritized, broken frustule fragments shown on Plate 2 (figs 6-8) is very difficult. Fenner (pers. comm., 2000) suggested several genera to which they could belong, including Archaemonadopsis, Trochosiropsis, Aulacodiscus, Pyrgodiscus or Sheshukovia. These genera are Late Cretaceous in age.
A number of notched spheres (P1. 1, figs 3-6; Pl. 2, fig. 3), which occur together with the diatoms, appear to be problematica of unknown affinity.

The better preservation of the foraminiferal tests makes their determination easier. The shape and the arrangement of the chambers and septa can be observed and the ornamentation (striae, spinae) of some biserial and trochospiral specimens is evident. Biserial, striate forms with a large last chamber, and slightly trochospiral ones with spines are present. Because no apertures were preserved and the wall structures cannot be reconstructed, determinations are questionable (Vergara-S. pers. comm., 1998). The biserial forms (P1. 3, figs 1, 8, 9, 12) are comparable with specimens figured by Perty (1988) as Heterohelix striata and Heterohelix pulchra. Heterohelix occurred mainly during Late Cretaceous times (Culver, 1993) and lived within the mid- and outer-shelf (Hart et al., 2005; Omana, 2006). The second species is slightly trochospiral (Pl. 3, fig. 2) and possesses short spines, which allows a comparison with specimens that Perty (1988) identified as Globigerinelloides, Hedbergella or Globotruncanella. However, some species of the genus Archaeoglobigerina (Caron, 1985; Norris, 1992) also look very similar.

The small size of the foraminiferal tests of about $100 \mu \mathrm{m}$ suggests that living conditions might not have been optimal; alternatively, only small specimens might have been pyritized.

All the radiolarian tests were broken and forms with a cephalis and thorax or abdomen belong to the Nassellaria, whilst those with spherical medullary shells and spines belong to Spumellaria. Both groups are very rare; nevertheless, fragments of the latter predominate, indicating marine shelf conditions (>200 m; Casey, 1993) rather than open ocean conditions, which are preferred by nassellarians. Because determination of radiolarian genera and species was impossible, a further stratigraphical assignment of the sediments is not possible.

\section{CONCLUSION}

Whilst pyritized microfossils occur commonly in some palynological slides from the Late Cretaceous of Colombia, these forms do not allow precise stratigraphical determination. However, palaeoecological interpretations can be made. The frequent presence of pyritized, but relatively well-ornamented, marine, planktonic fossil groups, including diatoms, radiolaria and foraminifera, points to normal marine conditions. Furthermore, the environment of deposition indicates a mid-outer shelf position.

The combined technique used herein (CRT) allows the investigation of opaque microfossils, whether carbonized or pyritic, and can be used for all palynological slides. Furthermore, pyrite can be distinguished easily from carbonized residues by the lower reflective values of the organic material.

\section{ACKNOWLEGEMENTS}

The Deutsche Forschungsgemeinschaft (DFG) supported the investigations and fieldwork. The authors are indebted to $\mathrm{J}$. Fenner and L. Vergara-S. for helpful determinations of the diatoms and foraminifera. D. E. G. Briggs and R. Coutts are thanked for geochemical investigations on the pyrite. The authors wish to thank M. Schorge for photographic work. Critical reading of the text by D. E. G. Briggs is acknowledged. 


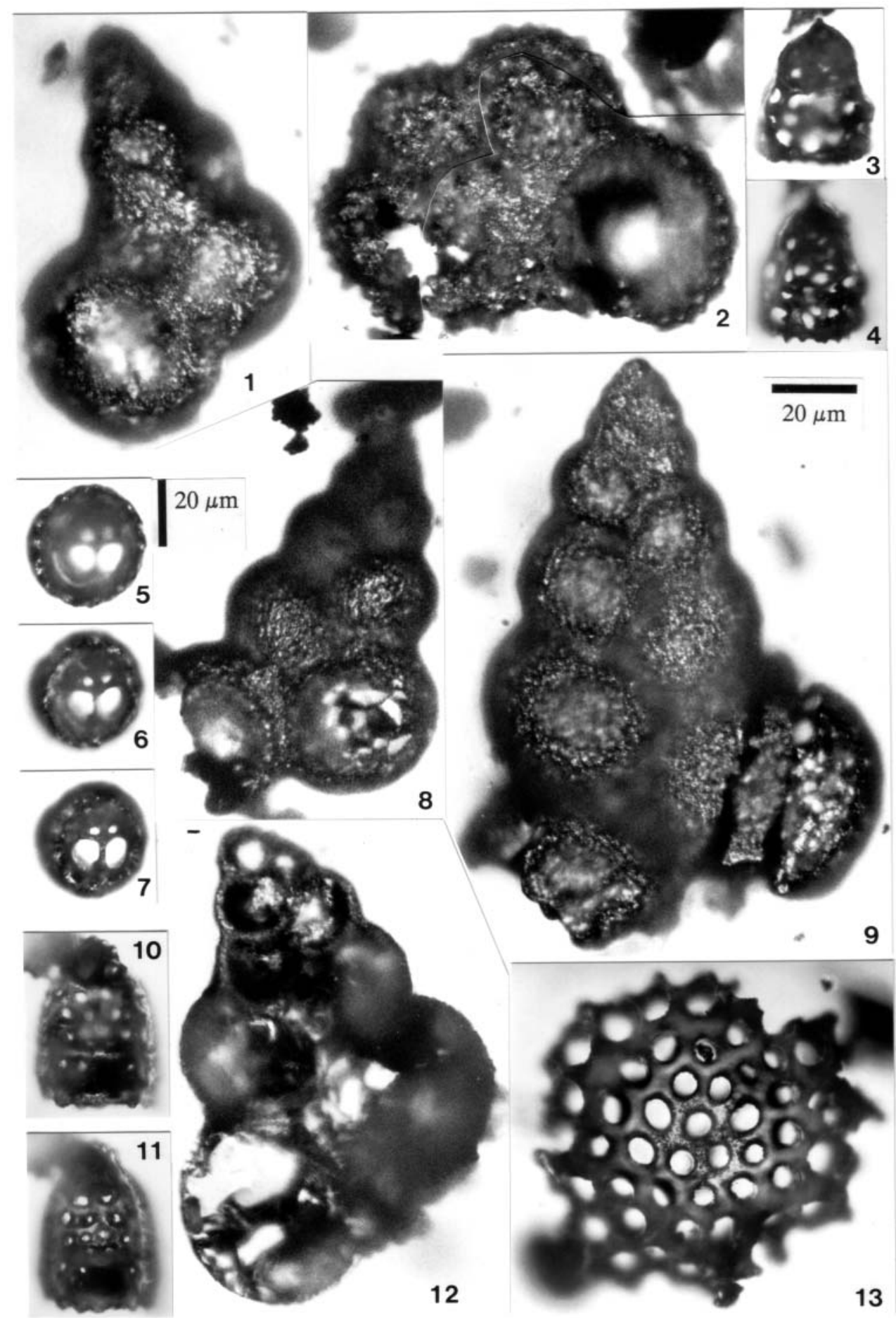

Explanation of Plate 3.

figs 1-13. Foraminifera and radiolaria: 1, pyritized (pseudomorphism) test of a biserial foraminifera (Heterohelix sp. cf. Heterohelix globulosa) (33-100); 2, pyritized slightly trochospiral foraminifera with conical elements, ventral view?; cf. Archaeoglobigerina sp. (38-98.8); 3, 4, Nassellarian radiolaria (39.9-104.5); 5, 6, 7, pyritized inner medullary shell of a spumellarian radiolaria (40-101.1); 8, Heterohelix sp. cf. Heterohelix globulosa biserial foraminifera, a broken chamber shows large internal pyrite crystals. On the surface a slight striation is recognizable (39.6-101.5); 9, Heterohelix sp. cf. Heterohelix pulchra biserial foraminifera; the pyritized test shows slight striation (32.7-98.5); 10, 11, Nassellarian radiolaria. (41.8-97.8); 12, Heterohelix sp. cf. Heterohelix globulosa biserial pyritized foraminifera with broken chambers. The septa with the foramen are visible (38.8-100.5); 13, pyritized fragment of a cortical or medullary shell belonging possibly to a spumellarian radiolaria (37.5-99.7). Magnification for figures $1-7$ and $9-13$ is $\times 750(20 \mu \mathrm{m}$ scale below fig. 4) and, for figure 8 , it is $\times 600(20 \mu \mathrm{m}$ scale right of fig. 5). All foraminifera of figures $1,2,8$, 9 and 12 are from slide 26-10-14-90, reference point 55.3-117.8. Radiolaria are from slide 26-10-01-90, reference point 53.8-117.2. Coordinates given for respective figures. Suggested age of samples is Late Cretaceous (Cenomanian/Turonian). All photomicrographs were taken with CRT/DIC. 
Thanks also to both the reviewers, F. J. Gregory and R. P. W. Stancliffe, for their essential comments.

\section{Manuscript received 16 January 2009 Manuscript accepted 13 February 2009}

\section{REFERENCES}

Barron, J.A. 1993. Diatoms. In: Lipps, J.H. (Ed.), Fossil Procaryotes and Protists. Blackwell Scientific Publications, London, 155-167.

Bartels, C., Briggs, D.E.G. \& Brassel, G. 1998. The fossils of the Hunsrück Slate. Marine life in the Devonian. Cambridge Paleobiology Series, 3: I-XIV, 309pp.

Cáceres-Girón, C. \& Etayo-Serna, F. 1969. Bosquejo geológico de la región del Tequendama. In: Primer Congreso Colombiano de Geologia, Opúsculo Guía de la Excursión Pre-Congreso, 1-22.

Canfield, D.E. \& Raiswell, R. 1991. Pyrite formation and fossil preservation. In: Allison, P.A. \& Briggs, D.E.G. (Eds), Taphonomy: Releasing the Data from the Fossil Record, Topics in Geobiology, 9. Plenum Press, New York, 337-387.

Caron, M. 1985. Cretaceous planktic foraminifera. In: Bolli, H.M., Saunders, J.B. \& Perch-Nielsen, K. (Eds), Plankton Stratigraphy. Cambridge University Press, Cambridge, 17-86.

Casey, R.E. 1993. Radiolaria. In: Lipps, J.H. (Ed.), Fossil Procaryotes and Protists. Blackwell Scientific Publications, London, 249-284.

Culver, S.J. 1993. Foraminifera. In: Lipps, J.H. (Ed.), Fossil Procaryotes and Protists. Blackwell Scientific Publications, London, 203-247.

Etayo-Serna, F. 1979. Zonation of the Cretaceous of central Colombia by ammonites. Publicaciones Geolócicas Especiales del Ingeominas, 2: $1-186$.

Gaupp, R. \& Batten, D.J. 1985. Maturation of organic matter in Cretaceous strata of the Northern Calcareous Alps. Neues Jahrbuch Geologie Paläontologie, Monatshefte, 1985(3): 157-175.

Geroch, S. 1973. Lower Cretaceous Diatoms in the Polish Carpathians. Rocznik Polskiego Towarzystwa Geologicznego, 48(3-4): 283-295.
Grösser, J.R. 1989. Geotectonic evolution of the Western Cordillera of Colombia: New aspects from geochemical data on volcanic rocks. Journal of South American Earth Sciences, 2: 359-369.

Hart, M.B., Callapez, P.M., Fisher, J.K., Hannant, K., Monteiro, J.F., Price, G.D. \& Watkinson, M.P. 2005. Micropalaeontology and Stratigraphy of the Cenomanian/Turonian boundary in the Lusitanian Basin, Portugal. Journal of Iberian Geology, 31(2): 311-326.

Krumbiegel, G. \& Krumbiegel, B. 1981. Fossilien der Erdgeschichte. Ferdinand Enke Verlag, Stuttgart, 406pp.

Marshall, K.L. \& Batten, D.J. 1988. Dinoflagellate cyst associations in Cenomanian-Turonian "black shale" sequences of northern Europe. Review of Palaeobotany Palynology, 54: 85-103.

McLaughlin, D. \& Arce, M. 1971. Recursos minerales de parte de los dptos de Cundinamarca Boyaca y Meta. Boletin Geologico, 19(1): $1-102$.

Norris, R.D. 1992. Umbilical structures in Late Cretaceous planktonic foraminifera. Micropalentology, 38(2): 165-181.

Omana, 1. 2006. Late Cretaceous (Maastrichtian) foraminiferal assemblage from the inoceramis beds, Ocozocoautla Formation, central Chiapas, SE Mexico. Revista Mexicana de Ciencias Geológicas, 23(2): 125-132.

Perty, D. 1988. Maastrichtian extinctions of planktonic Foraminifera in central and eastern Poland. Revista Española de Paleontología, 3: 105-115.

Prössl, K.F. 1992. Preliminary results from palynological investigations on the Cretaceous of Colombia, South America. Review of Palaeobotany Palynology, 71: 255-268.

Prössl, K.F. 1996. About the preservation of palynomorphs in sediments, with special regard to their microscopic study. Scientific and Technical Information, XI(3): 90-95.

Prössl, K.F. 1997. Paläopalynologie. Teil I: Grundlagen und Methoden. Mikrokosmos, 86(6): 341-349.

Traverse, A. 1988. Paleopalynology, I-XXIII. Unwin Hyman, Boston, $600 \mathrm{pp}$. 